\title{
Growth Response of Herbaceous Ornamentals to Phosphorus Fertilization
}

\author{
Josh B. Henry ${ }^{1}$, Ingram McCall, Brian Jackson, and Brian E. Whipker \\ Department of Horticultural Science, North Carolina State University, P.O. \\ Box 7609, Raleigh, NC 27695
}

Additional index words. floriculture, nutrient deficiency, phosphate, plant growth control

\begin{abstract}
A series of experiments investigated the effects of increasing phosphatephosphorus (P) concentrations on the growth and development of four horticultural species. In experiment 1, petunia [Petunia atkinsiana (Sweet) D. Don ex W.H. Baxter] plants were grown using eight $P$ concentrations, and we found that the upper bound for plant growth was at $8.72-9.08 \mathrm{mg} \cdot \mathrm{L}^{-1} \mathrm{P}$, whereas concentrations $\leq 2.5 \mathrm{mg} \cdot \mathrm{L}^{-1} \mathrm{P}$ caused $\mathrm{P}$ deficiency symptoms. Experiment 2 investigated $P$ growth response in two cultivars each of New Guinea impatiens (Impatiens hawkeri W. Bull) and vinca [Catharanthus roseus (L.) G. Don]. Growth for these plants was maximized with $6.43-12.42 \mathrm{mg} \cdot \mathrm{L}^{-1} \mathrm{P}$. In experiment 3, ornamental peppers (Capsicum annuum $\mathrm{L}$. 'Tango Red') were given an initial concentration of $P$ for 6 weeks and then switched to $0 \mathrm{mg} \cdot \mathrm{L}^{-1} P$ to observe whether plants could be supplied with sufficient levels of $P$, and finished without $P$ to keep them compact. Plants switched to restricted $P$ began developing $P$ deficiency symptoms within 3 weeks; however, restricting $P$ successfully limited plant growth. These experiments indicated that current $P$ fertilization regimens exceed the $P$ requirements of these bedding plants, and depending on species, concentrations of 5-15 $\mathrm{mg} \cdot \mathrm{L}^{-1} \mathrm{P}$ maximize growth.
\end{abstract}

Producers of floriculture crops strive to cultivate compact and healthy plants that are considered high quality and attractive for consumers. The fertilization regimen has a significant role in the ultimate appearance and robustness of a crop. Many commercial fertilizers mixed at recommended concentrations for greenhouse production supply greater phosphorus $(\mathrm{P})$ concentrations than required by plants, as is the case with 20 nitrogen $(\mathrm{N})$ 8.7P-16.6 potassium $(\mathrm{K})$. This fertilizer mixed at a concentration of $200 \mathrm{mg} \cdot \mathrm{L}^{-1} \mathrm{~N}$ would provide $87 \mathrm{mg} \cdot \mathrm{L}^{-1} \mathrm{P}$. One recommendation for greenhouse crops by McMahon (2011) suggests using concentrations of only $5-10$ $\mathrm{mg} \cdot \mathrm{L}^{-1} \mathrm{P}$. Other studies have indicated that $\mathrm{P}$ concentrations of just $0.093-1.5 \mathrm{mg} \cdot \mathrm{L}^{-1}$ can keep floriculture crops healthy yet compact (Borch et al., 1998; Hansen and Nielsen, 2000, 2001). This disparity among $P$ recommendations and $\mathrm{P}$ concentrations supplied in common fertilizers brings into question what level of $\mathrm{P}$ is required to produce healthy floriculture crops.

\footnotetext{
Received for publication 21 June 2017. Accepted for publication 21 Aug. 2017.

We are grateful for the funding support provided by the Fred C. Gloeckner Foundation, the USDA Floriculture and Nursery Research Initiative, American Floral Endowment Altman Family Scholarship, and The Garden Club of America. We would also like to express our gratitude to Dümmen Orange for providing cuttings and for peat moss provided by Sun Gro Horticulture.

${ }^{1}$ Corresponding author. E-mail: josh.brady.henry@ gmail.com.
}

Recent research investigated the minimum $\mathrm{P}$ concentrations required by herbaceous ornamentals (Borch et al., 1998; Hansen and Nielsen, 2000, 2001; Nelson et al., 2012). These studies were focused on the potential of using low P fertilization to control plant growth. Although the nitrate $\left(\mathrm{NO}_{3}{ }^{-}\right)$form of $\mathrm{N}$ has often been used to keep plants compact, it is the low $\mathrm{P}$ levels in high $\mathrm{NO}_{3}{ }^{-}-\mathrm{N}$ fertilizers that are responsible for compactness (Nelson et al., 2012). Most $\mathrm{NO}_{3}{ }^{-}$based fertilizers recommended for compact plant growth are also low in $\mathrm{P}$. Erroneously, it was thought that fertilizer formulations high in ammoniacal nitrogen $\left(\mathrm{NH}_{4}{ }^{+}\right)$result in greater plant growth. Experiments conducted by Nelson et al. (2002) used constant ratios of $\mathrm{N}$ source, but varied $\mathrm{P}$ concentrations, and found that plant size increased with increasing $\mathrm{P}$ concentrations. Previously, it was thought that higher $\mathrm{P}$ concentrations would only increase growth until plant $\mathrm{P}$ concentration reached $0.25 \%$ of total dry matter (Nelson et al., 2002).

Potential issues with very low $\mathrm{P}$ fertilization result from the fact that the soilless substrates used in floriculture production have limited $\mathrm{P}$ holding capacity (Marconi and Nelson, 1984). Without adequate $P$, crops have the potential to deplete the initial $\mathrm{P}$ concentration in the substrate and may begin reallocating $\mathrm{P}$ from older plant tissues, leading to the development of deficiency symptoms on the lower leaves (Mengel et al., 2001). Deficiency symptoms associated with $\mathrm{P}$ are commonly observed when dry plant tissue comprises $<0.2 \%$ or $2000 \mathrm{mg} \cdot \mathrm{kg}^{-1}$ P (Mills and Jones, 1996). Typical symptoms are often described as a reddening or purpling of the lower foliage, an overall darker green coloration, stunted growth, delayed flowering, and greater root lengths (Epstein and Bloom, 2005; Marschner, 1995; Mengel et al., 2001). For leaf tissue concentrations, a range of $0.2 \%$ to $0.5 \%$ of total plant dry weight is considered sufficient P for most plants (Mills and Jones, 1996).

This study aimed to determine the $\mathrm{P}$ concentration required by several floriculture species to optimize growth. Determining optimal P concentrations will provide improved grower recommendations and limit commercial fertilizer waste.

\section{Materials and Methods}

Experiment 1. Two cultivars of petunia [Petunia atkinsiana (Sweet) D. Don ex W.H. Baxter 'Surprise Sky Blue' and 'Potunia Neon'] cuttings (Dümmen Orange, Columbus, $\mathrm{OH}$ ) were planted on 28 Sept. 2015 in 128 cell plug trays with cell dimensions of $2.7 \times 2.7 \times 3.8 \mathrm{~cm}$ (length $\times$ width $\times$ depth $)$ and rooted under mist without fertilization. Plants were propagated and grown in a glassglazed greenhouse at North Carolina State University, Raleigh, NC ( $35^{\circ} \mathrm{N}$ latitude) under natural photoperiod. Greenhouse day/night temperature set points were $23.9 / 18.3{ }^{\circ} \mathrm{C}$, and the average daily temperature (ADT) was $19.7^{\circ} \mathrm{C}$. The substrate used for all aspects of the experiment was an 80:20 (v:v) mix of Canadian sphagnum peatmoss (Conrad Fafard, Agawam, MA) and horticultural coarse perlite (Perlite Vermiculite Packaging Industries, Inc., North Bloomfield, $\mathrm{OH}$ ), amended with dolomitic limestone at $8.875 \mathrm{~kg} \cdot \mathrm{m}^{-3}$ (Rockydale Agricultural, Roanoke, VA) and wetting agent (AquaGro $2000 \mathrm{G}$; Aquatrols, Cherry Hill, NJ) at $600.3 \mathrm{~g} \cdot \mathrm{m}^{-3}$. This custom substrate was used to ensure that there was no initial $\mathrm{P}$ concentration. Twenty-eight-day old rooted cuttings were transplanted into $12.7 \mathrm{~cm}$ diameter $(855$ $\mathrm{mL}$ ) pots (Dillen, Middlefield, $\mathrm{OH}$ ).

Concentrations of $0,1.25,2.5,5,10,20$, 40 , and $80 \mathrm{mg} \cdot \mathrm{L}^{-1} \mathrm{P}$ were used to determine the upper and lower bounds of growth response to P. The experiment was completely randomized with eight single-plant replications of eight treatments. Fertilization began at transplant, and fertilizers were custom blends of the following individual technical grade salts: calcium nitrate tetrahydrate $\left[\mathrm{Ca}\left(\mathrm{NO}_{3}\right)_{2} \cdot 4 \mathrm{H}_{2} \mathrm{O}\right]$, potassium nitrate $\left(\mathrm{KNO}_{3}\right)$, monopotassium phosphate $\left(\mathrm{KH}_{2} \mathrm{PO}_{4}\right)$, potassium sulfate $\left(\mathrm{K}_{2} \mathrm{SO}_{4}\right)$, magnesium sulfate heptahydrate $\left(\mathrm{MgSO}_{4} \cdot 7 \mathrm{H}_{2} \mathrm{O}\right)$, magnesium nitrate $\left[\mathrm{Mg}\left(\mathrm{NO}_{3}\right)_{2}\right]$, iron chelate (FeDTPA), manganese chloride tetrahydrate $\left(\mathrm{MnCl}_{2} \cdot 4 \mathrm{H}_{2} \mathrm{O}\right)$, zinc chloride heptahydrate $\left(\mathrm{ZnCl}_{2} \cdot 7 \mathrm{H}_{2} \mathrm{O}\right)$, copper chloride dihydrate $\left(\mathrm{CuCl}_{2} \cdot 2 \mathrm{H}_{2} \mathrm{O}\right)$, boric acid $\left(\mathrm{H}_{3} \mathrm{BO}_{3}\right)$, and sodium molybdate dihydrate $\left(\mathrm{Na}_{2} \mathrm{MoO}_{4} \cdot 2 \mathrm{H}_{2} \mathrm{O}\right)$. Phosphorus (referring to phosphate-phosphorus) concentrations were varied among treatments whereas other essential nutrients were adjusted to remain as constant as possible. $\mathrm{NO}_{3}^{-} \mathrm{N}$ and $\mathrm{K}$ were held at $150 \mathrm{mg} \cdot \mathrm{L}^{-1}$, with all other essential microelements remaining constant (Henry, 2017). 
Fertilizer solution was mixed in 100-L barrels and applied manually as needed at every irrigation with a $10 \%$ leaching fraction. Solution was delivered via sump pumps (Model 1A; Little Giant Pump Co., Oklahoma City, OK) connected to $1.9-\mathrm{cm}$ black irrigation tubing fitted with drip rings (Dramm USA, Manitowoc, WI). This method of applying the fertilizer solution at every irrigation was referred to as a constant liquid feed fertilization program.

Both petunia cultivars were destructively harvested after 8 weeks. Plant diameter was recorded by averaging the widest point and its perpendicular axis. Final substrate $\mathrm{pH}$ and electrical conductivity (EC) were obtained using the Pour-Thru method (Cavins et al., 2005) and recorded using a portable meter (HI 9813-6; Hanna Instruments, Woonsocket, RI), and leachate was submitted for analysis at the North Carolina Department of Agriculture \& Consumer Service (NCDA\&CS, Raleigh, NC). Most recently matured leaves were sampled for tissue analysis and were washed in a solution of $0.5 \mathrm{M}$ hydrochloric acid $(\mathrm{HCl})$, followed by a rinse of deionized water. The remaining shoot tissue was cut off level with the substrate and dried. Tissue samples were dried for $72 \mathrm{~h}$ at $70{ }^{\circ} \mathrm{C}$, and total plant dry mass was recorded. After drying, tissue samples were ground using a tissue mill (Thomas Wiley ${ }^{\circledR}$ Mini-Mill; Thomas Scientific, Swedesboro, $\mathrm{NJ}$ ), and analyzed for nutrient concentrations by AgSource Laboratories (Lincoln, NE). Total $\mathrm{N}$ was processed by Kjeldahl digestion and determined via flow injection analysis. Extractable $\mathrm{K}$ was processed by $2 \%$ acetic acid digestion, and determined via inductively coupled plasma mass spectrometry (ICP-MS). Total P and all other plant minerals were processed by nitric acid/hydrogen peroxide digestion and determined via ICP-MS.

Experiment 2. Two cultivars each of vinca [Catharanthus roseus (L.) G. Don] and New Guinea impatiens (Impatiens hawkeri W. Bull) were grown in this study to investigate $\mathrm{P}$ growth response over time. Seeds of vinca (Fred C. Gloeckner \& Co., Inc., Harrison, NY) and unrooted cuttings of New Guinea impatiens (Dümmen Orange) were propagated in 128-cell plug trays as previously described. The greenhouse, temperature set points, and substrate were the same as in experiment 1. 'Cora Burgundy' and 'Pacifica Blush XP' vinca were seeded on 23 Apr. 2016, whereas 'Tamarinda Dark Red' and 'Pure Beauty Red on Pink' New Guinea impatiens cuttings were stuck on 3 May 2016.

New Guinea impatiens were transplanted on 24 May into $12.7 \mathrm{~cm}$ diameter $(855 \mathrm{~mL})$ pots (Dillen), and vinca were transplanted into $11.4-\mathrm{cm}$ diameter $(600 \mathrm{~mL})$ standard pots (Dillen) on 2 June. During the experiment, the ADT was $23.7{ }^{\circ} \mathrm{C}$. Plants were grown under natural photoperiod, with $50 \%$ shadecloth (Ludwig Svensson Inc., Charlotte, NC) drawn between 1100 and $1500 \mathrm{HR}$. P fertilizer treatments of $0,2.5,5,10$, or 20 $\mathrm{mg} \cdot \mathrm{L}^{-1}$ were mixed and applied using the methods from experiment 1 . Tubing was fitted with either drip rings (Dramm USA) for New Guinea impatiens or Dribble Tubes (Dramm USA) for vinca. Biweekly measurements were collected for plant height and diameter. Plant height was measured from the rim of the pot to the highest point on the plant. Although pots were filled to the same level with substrate, some settling may have occurred, and measuring from the rim of the pot was chosen to maintain consistency. Diameter was measured using the methods from experiment 1 .

A final destructive harvest was conducted 7 weeks after transplant for vinca and 10 weeks after transplant for New Guinea impatiens. Plant measurements, including height, diameter, and dry mass were recorded using the methods previously described.

Experiment 3. This study investigated whether plants could be grown with a higher initial $\mathrm{P}$ concentration, and later restricted to maintain a compact size. Ornamental pepper (Capsicum annuum 'Tango Red') seeds (Fred C. Gloeckner \& Co., Inc.) were sown on 6 Apr. 2016 into 1204 flat inserts with cell dimensions of $5.7 \times 3.8 \times 5.4 \mathrm{~cm}$ (length $\times$ width $\times$ depth) and volume of $103 \mathrm{~mL}$. The greenhouse, temperature set points, and substrate were the same as in experiment 1 . Peppers were transplanted on 13 May into $13.7 \mathrm{~cm}(1.28 \mathrm{~L})$ diameter pots (Dillen). Plants were initially grown with concentrations of $0,2.5,5,10$, and $20 \mathrm{mg} \cdot \mathrm{L}^{-1} \mathrm{P}$ mixed and applied using the methods from experiment 1 . After 6 weeks, 12 plants from each nonzero $\mathrm{P}$ concentration were switched to $0 \mathrm{mg} \cdot \mathrm{L}^{-1} \mathrm{P}$, and 12 plants remained on their original $\mathrm{P}$ concentration. All pots received a drench of clear water with a $50 \%$ leaching fraction, to leach $P$ from the substrate.

Tissue samples were collected from four single plant replicates at 6 and 9 weeks after transplant using the methods from experiment 1 . The experiment was ended 11 weeks after transplant. Six individual plant replications were then measured and destructively harvested. Plant height, diameter, and dry mass were recorded using the previously described methods. Substrate $\mathrm{pH}$ and EC were recorded, and leachate from four single plants replicates was submitted to NCDA\&CS for nutrient analysis. Tissue samples of the most recently matured leaves were also collected from four single plant replicates, and handled using procedures previously described for nutrient analysis.

Statistical analysis. Height, diameter, and dry mass were analyzed and used to calculate growth index (GI) Eq. [1] which was based on the equation for GI presented by Krug et al. (2010).

$\mathrm{GI}=\frac{\text { height }+\frac{\text { diameter } 1+\text { diameter } 2}{2}+\text { drymass }}{3}$

[1]

For petunia, a modified GI was calculated which excluded height, because height was not measured for this species.

All data were analyzed using SAS (version 9.4; SAS Institute, Cary, NC) and GraphPad Prism (version 7.02; GraphPad
Software, Inc., La Jolla, CA). Height, diameter, dry mass, substrate $\mathrm{pH}$, and $\mathrm{EC}$ data were subjected to PROC GLIMMIX. The least squared means were separated by Tukey's HSD at $P \leq 0.05$. Data were combined between cultivars whenever there were no interactions between $\mathrm{P}$ concentration and cultivar. PROC REG was used to regress the data and determine the best fit quadratic model for the different $\mathrm{P}$ concentrations. PROC NLIN was also used to determine best fit quadratic plateau models Eq. [2] for each growth parameter.

$$
Y_{i}= \begin{cases}\beta_{0}+\beta_{1} X_{i}+\beta_{1} X_{i}^{2}+\varepsilon_{i} & \text { if } X<X_{0} \\ Y_{0}+\varepsilon_{i} & \text { if } X \geq X_{0}\end{cases}
$$

where

$$
\begin{gathered}
X_{0}=-\frac{\widehat{\beta}_{1}}{2 \widehat{\beta}_{2}}, \text { and } \\
Y_{0}=\widehat{\beta}_{0}-\frac{\widehat{\beta}_{1}^{2}}{4 \widehat{\beta}_{2}}
\end{gathered}
$$

Quadratic models obtained from PROC REG and quadratic plateau models obtained from PROC NLIN were then compared using GraphPad Prism and selected based on the difference between corrected Akaike information criterion (AICc) values (Spiess and Neumeyer, 2010). Models with the lowest AICc were selected. $X_{0}$ values provided for growth plateaus indicate the $\mathrm{P}$ concentration at which each growth parameter reached its maximum, past which point no growth increase occurred.

\section{Results}

Experiment 1. Petunias grown with $<5 \mathrm{mg} \cdot \mathrm{L}^{-1} \mathrm{P}$ exhibited $\mathrm{P}$ deficiency symptoms, ranging from mild to severe stunting, with lower leaf chlorosis, necrosis, and in many cases, complete floral inhibition (J.B. Henry, visual observations). Quadratic regression models with plateaus provided a best fit for diameter, which plateaued at 8.81 and $8.31 \mathrm{mg} \cdot \mathrm{L}^{-1} \mathrm{P}$, respectively for 'Potunia Neon' and 'Surprise Sky Blue' (Table 1). The amount of $P$ required to reach these growth plateaus was similar for both cultivars, despite that the maximum diameter of 'Surprise Sky Blue' was nearly double that of 'Potunia Neon'. The GI provides a more accurate account of where maximum growth was achieved for each cultivar (Fig. 1). Maximum growth was reached for 'Surprise Sky Blue' and 'Potunia Neon' at 8.72 and 9.08 $\mathrm{mg} \cdot \mathrm{L}^{-1} \mathrm{P}$, respectively. This indicates that optimal $\mathrm{P}$ concentrations of $\approx 9 \mathrm{mg} \cdot \mathrm{L}^{-1}$ provide maximum growth for these two petunia cultivars.

Foliar $\mathrm{P}$ concentrations ranged from $0.05 \%$ in plants grown without $\mathrm{P}$, up to $1.21 \%$ in plants grown with $80 \mathrm{mg} \cdot \mathrm{L}^{-1} \mathrm{P}$ (data not shown). Plants grown with 80 $\mathrm{mg} \cdot \mathrm{L}^{-1} \mathrm{P}$ had significantly higher foliar $\mathrm{P}$ concentrations than plants grown with any 
Table 1. Best fit (Adj- $\left.R^{2}, \mathrm{AICc}, \mathrm{DIF}^{\mathrm{z}}\right)$ quadratic or quadratic plateau regression models for growth index, height, and diameter with optimal phosphorus (P) concentration indicated by $X_{0}$ values.

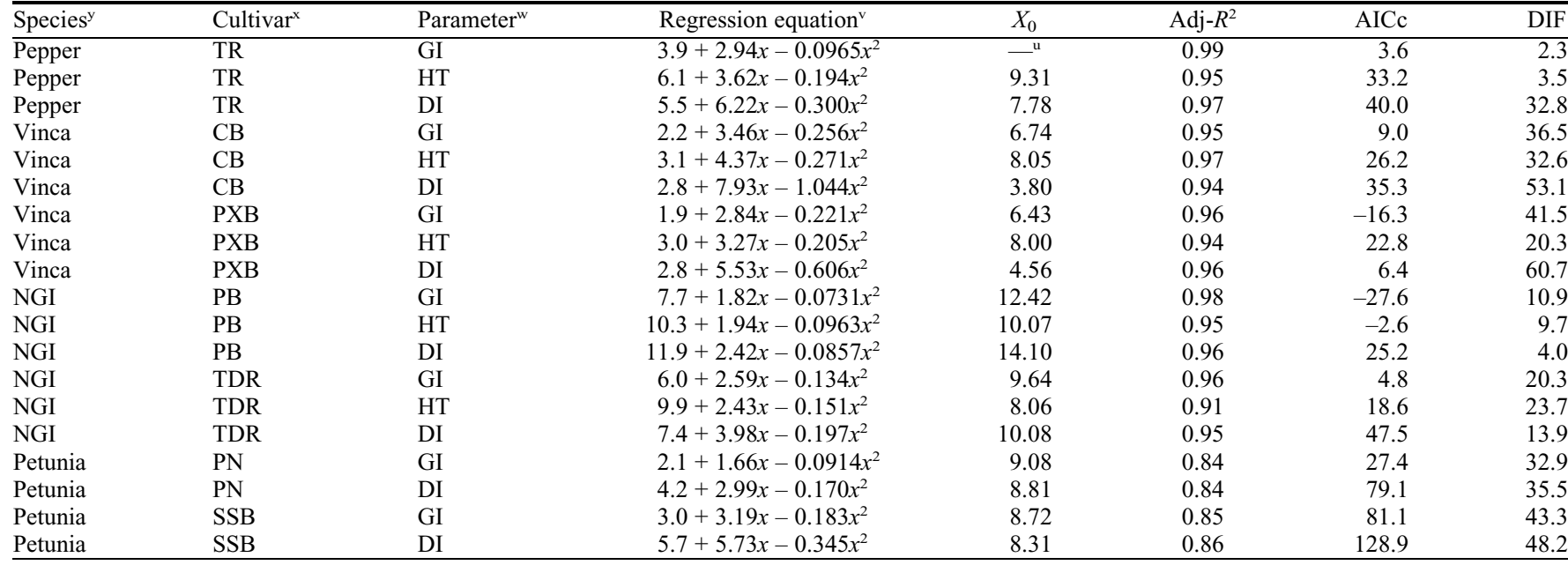

${ }^{\mathrm{z}}$ Best fit statistics: Adj- $R^{2}=$ adjusted coefficient of determination; AICc $=$ corrected Akaike information criteria; DIF = difference in selected model AICc from inferior model AICc.

${ }^{\text {y} S p e c i e s: ~ P e p p e r ~(C a p s i c u m ~ a n n u u m) ; ~ V i n c a ~(C a t h a r a n t h u s ~ r o s e u s) ; ~ N G I ~=~ N e w ~ G u i n e a ~ i m p a t i e n s ~(I m p a t i e n s ~ h a w k e r i) ; ~ P e t u n i a ~(P e t u n i a ~ a t k i n s i a n a) . ~}$

${ }^{\mathrm{x}}$ Cultivar: TR = Tango Red; $\mathrm{CB}=$ Cora Burgundy; $\mathrm{PXB}=$ Pacifica XP Blush; PB = Pure Beauty Red on Pink; TDR = Tamarinda Dark Red; PN = Potunia Neon; SSB $=$ Surprise Sky Blue.

${ }^{\text {w}}$ Parameter: GI = growth index; $\mathrm{HT}=$ height; $\mathrm{DI}=$ diameter.

${ }^{v}$ Models significant at $P \leq 0.0001$.

${ }^{\mathrm{u}}$ No $X_{0}$ value indicates selection of a quadratic model, so no $X_{0}$ value was reported.

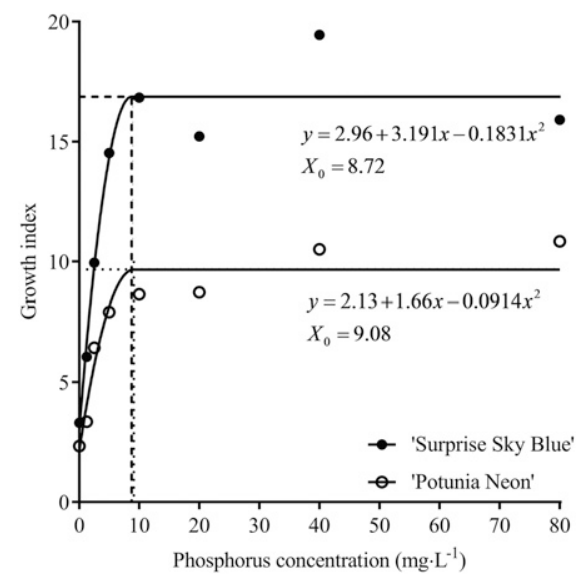

Fig. 1. Nonlinear regression plateaus and quadratic regression model for growth index (GI) of petunia (Petunia atkinsiana) 'Surprise Sky Blue' and 'Potunia Neon' on termination of the experiment. Regression lines were generated from means of each treatment $(n=8)$. Equations and $X_{0}$ values for plateau models are located below the corresponding lines. Dotted lines represent the $X_{0}$ values, where the model plateaus, along with corresponding GI. Models significant at $P \leq 0.0001$

other $\mathrm{P}$ concentration. This alludes to the fact that plants exhibit luxury $\mathrm{P}$ consumption after having reached maximum size in response to P (Nelson et al., 2012).

Experiment 2. Over the course of 10 weeks, height and diameter of New Guinea impatiens plants followed similar overall growth trends (Fig. 2A-D). Means of plant height were plotted for 'Tamarinda Dark Red' to compare P concentrations over time. Plants grown with 5 and $10 \mathrm{mg} \cdot \mathrm{L}^{-1} \mathrm{P}$ increased with a similar trend. Plants grown with $2.5 \mathrm{mg} \cdot \mathrm{L}^{-1} \mathrm{P}$ had similar height to plants grown with greater concentrations for the initial 4 weeks, before trends diverged, and increases in plant height were less over time (Fig. 2A). Weekly means for 'Pure Beauty Red on Pink' heights were similar between plants grown with 10 and $20 \mathrm{mg} \cdot \mathrm{L}^{-1} \mathrm{P}$, with lower concentrations following similar increasing trends over time (Fig. 2B).

Diameter of 'Tamarinda Dark Red' increased over time for plants grown at all $\mathrm{P}$ concentrations, except those grown without $P$ (Fig. 2C). Plants grown without $\mathrm{P}$ exhibited decreasing overall diameter, which was due to changes in overall leaf architecture. Over time, leaves of 'Tamarinda Dark Red' plants grown without $\mathrm{P}$ became upward oriented, resulting in plants having a narrower appearance (Fig. 3A). Diameter of 'Pure Beauty Red on Pink' exhibited a similar trend as 'Tamarinda Dark Red', with the exception that plants grown without $\mathrm{P}$ also increased in diameter over time (Fig. 2D). Although 'Pure Beauty Red on Pink' plants were still severely stunted (Fig. 3B), they were not as severely effected as 'Tamarinda Dark Red'.

Quadratic growth plateau models demonstrate optimal concentrations of $\mathrm{P}$ for height and diameter of each New Guinea impatiens cultivar. The model for height indicated that maximum height was achieved using $\mathrm{P}$ concentrations of $10.07 \mathrm{mg} \cdot \mathrm{L}^{-1}$ for 'Pure Beauty Red on Pink' and $8.06 \mathrm{mg} \cdot \mathrm{L}^{-1}$ for 'Tamarinda Dark Red' (Table 1). After this point, there was no significant increase in plant height with increasing $\mathrm{P}$ concentrations. The model for diameter indicated that maximum diameter was achieved with $14.1 \mathrm{mg} \cdot \mathrm{L}^{-1} \mathrm{P}$ for 'Pure Beauty Red on Pink' and $10.08 \mathrm{mg} \cdot \mathrm{L}^{-1}$ $\mathrm{P}$ for 'Tamarinda Dark Red. This demonstrates that although maximum height was reached with $\mathrm{P}$ concentrations of $\approx 8-10 \mathrm{mg} \cdot \mathrm{L}^{-1}$, diameter still increased with higher $\mathrm{P}$ concentrations. Plateaus for GI indicated that 'Pure Beauty Red on Pink' reached maximum growth with $12.42 \mathrm{mg} \cdot \mathrm{L}^{-1} \mathrm{P}$, and 'Tamarinda Dark Red' reached maximum growth with $9.64 \mathrm{mg} \cdot \mathrm{L}^{-1} \mathrm{P}$ (Table 1$)$.

Vinca 'Cora Burgundy' plants exhibited similar increasing trends for plant height over the course of 6 weeks for all $P$ concentrations, except $0 \mathrm{mg} \cdot \mathrm{L}^{-1}$ (Fig. $4 \mathrm{~A}$ and B). Plants grown without $\mathrm{P}$ were stunted for the entire experiment in terms of overall height, and were roughly the same size as they had been before transplant. 'Cora Burgundy' and 'Pacifica XP Bush' plants grown without $\mathrm{P}$ did not increase in height over time (Fig. 4A and $\mathrm{B}$ ), and appeared similar to the plugs that had been transplanted at the beginning of the experiment, 6 weeks earlier.

Trends in diameter of 'Cora Burgundy', and 'Pacifica XP Blush' both indicate that maximum diameter was achieved for each $P$ concentration after 4 weeks of growth (Fig. 4C and D). Both cultivars exhibited high levels of growth between 2 and 4 weeks after transplant for all $\mathrm{P}$ concentrations except $0 \mathrm{mg} \cdot \mathrm{L}^{-1}$ (Fig. 4C and D). Without P, plants did not increase in size over time (Fig. 4A-D), and did not produce flowers. In contrast, plants grown with $2.5 \mathrm{mg} \cdot \mathrm{L}^{-1} \mathrm{P}$ grew over time and matured to the point of producing flowers, but were stunted and exhibited mild symptoms of chlorosis on the lower leaves. This indicates that vinca does not require high amounts of $\mathrm{P}$, but was severely affected without any external $P$ supply. This severe stunting may also have occurred because these plants were grown from seed, whereas New Guinea impatiens were grown from cuttings. Cuttings likely 

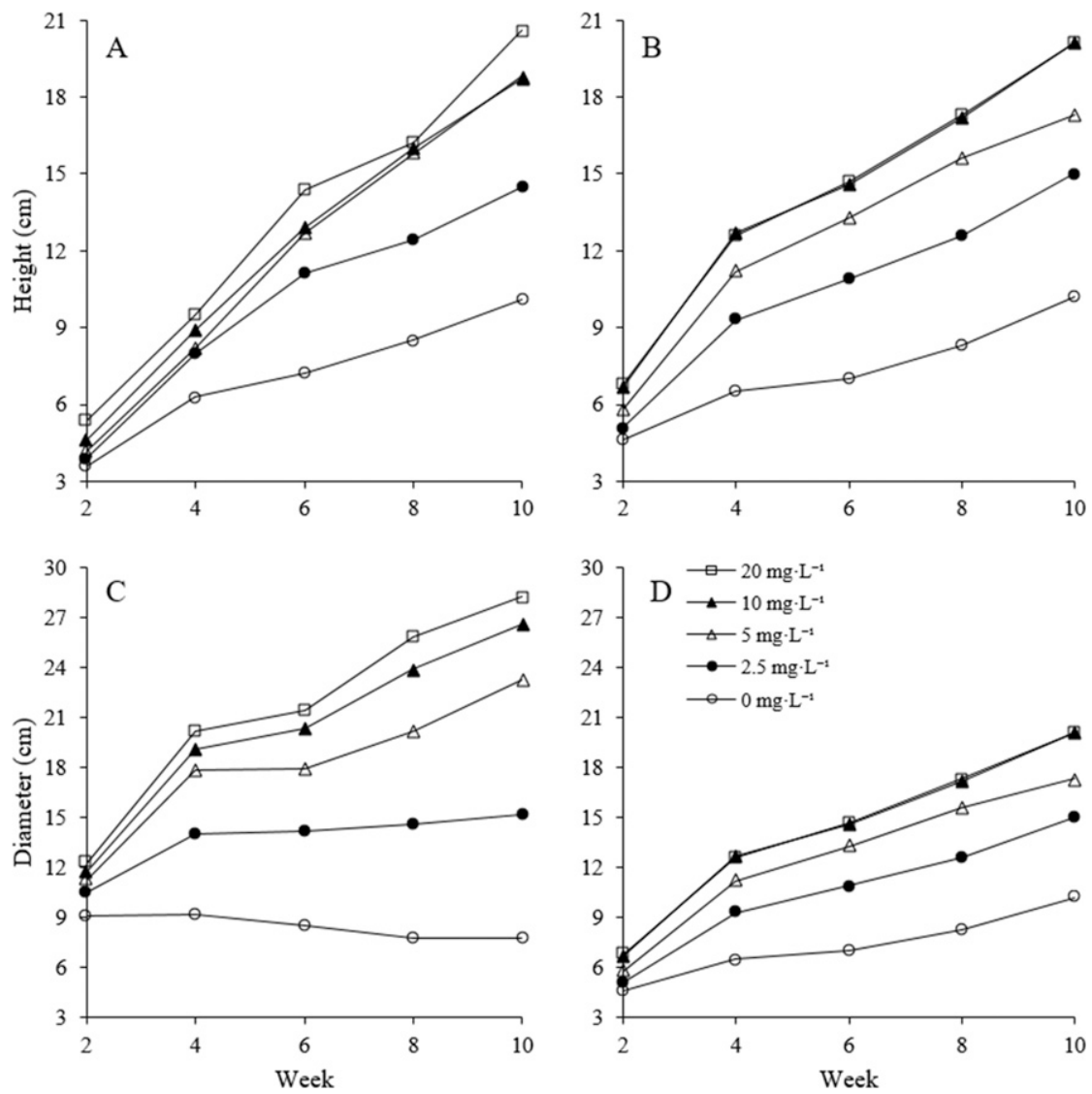

Fig. 2. Effect of five different fertilizer P concentrations on growth means of New Guinea impatiens (Impatiens hawkeri) 'Tamarinda Dark Red' and 'Pure Beauty Red on Pink' over a 10-week period. Growth in terms of (A) height and (C) diameter of 'Tamarinda Dark Red', compared with (B) height and (D) diameter of 'Pure Beauty Red on Pink'.

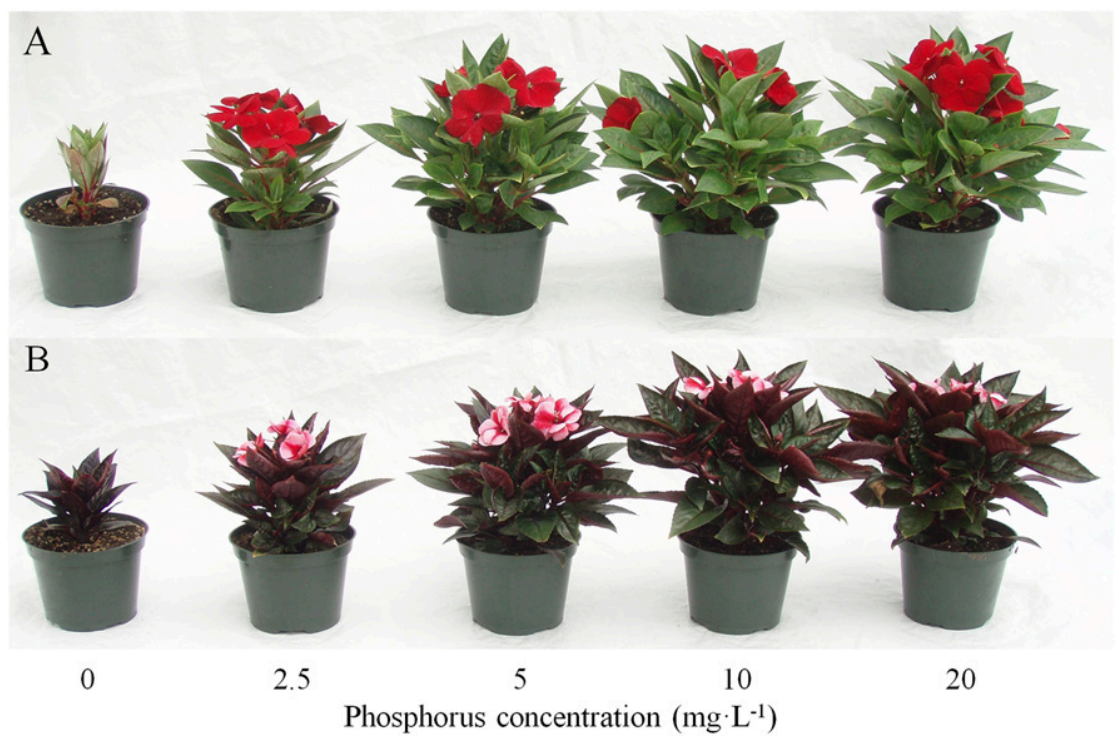

Fig. 3. New Guinea impatiens (Impatiens hawkeri) plants grown using P concentrations of $0,2.5,5,10$, and $20 \mathrm{mg} \cdot \mathrm{L}^{-1}$ over the course of 10 weeks. (A) 'Tamarinda Dark Red' may be seen in the top row, and (B) 'Pure Beauty Red on Pink' in the bottom row. Visual differences in plant size, flowering, and overall leaf architecture may be observed.

have higher P reserves than the small seeds of vinca, indicating that plants grown from cuttings could still achieve some level of growth without an external $\mathrm{P}$ supply.
Growth plateaus for vinca indicated that maximum height was achieved for 'Cora Burgundy' and 'Pacifica XP Blush' using $\mathrm{P}$ concentrations of 8.05 and $8.0 \mathrm{mg} \cdot \mathrm{L}^{-1}$, respectively (Table 1). This illustrates that although these two cultivars exhibited different maximum height, they achieved their individual maxima with similar $P$ concentrations. Growth plateaus for diameter indicated that maximum diameters for 'Cora Burgundy' and 'Pacifica XP Blush' occurred with 3.8 and $4.56 \mathrm{mg} \cdot \mathrm{L}^{-1}$, respectively. These concentrations are very low, indicating that vinca requires low $\mathrm{P}$ concentrations to achieve maximum diameter. Overall GI values demonstrate that 'Cora Burgundy' required $6.74 \mathrm{mg} \cdot \mathrm{L}^{-1} \mathrm{P}$ to achieve maximum growth, while 'Pacifica XP Blush' required $6.43 \mathrm{mg} \cdot \mathrm{L}^{-1} \mathrm{P}$. Little difference was observed between optimal $\mathrm{P}$ concentrations for these two cultivars (Table 1).

Experiment 3. At termination of the experiment, height was greatest for pepper plants grown with continuous concentrations of 10 and $20 \mathrm{mg} \cdot \mathrm{L}^{-1} \mathrm{P}$, or an initial concentration of $20 \mathrm{mg} \cdot \mathrm{L}^{-1} \mathrm{P}$, and plants grown without $\mathrm{P}$ were the shortest (Table 2). Diameters for plants grown with continuous 10 and $20 \mathrm{mg} \cdot \mathrm{L}^{-1} \mathrm{P}$ were the greatest, while plants grown without $\mathrm{P}$ were the smallest. Dry mass was greatest for plants grown with $20 \mathrm{mg} \cdot \mathrm{L}^{-1} \mathrm{P}$, and was least for plants grown with $0 \mathrm{mg} \cdot \mathrm{L}^{-1} \mathrm{P}$, or initial concentrations of $2.5 \mathrm{mg} \cdot \mathrm{L}^{-1} \mathrm{P}$. GI was least for plants grown without $\mathrm{P}$ and greatest for plants grown with 10 or $20 \mathrm{mg} \cdot \mathrm{L}^{-1} \mathrm{P}$. This demonstrates that growth of 'Tango Red' ornamental peppers can be controlled by using continuous concentrations less than $10 \mathrm{mg} \cdot \mathrm{L}^{-1} \mathrm{P}$, or any restricted $\mathrm{P}$ concentration.

Although low or restricted P concentrations successfully controlled growth, several pepper plants developed detrimental symptoms of $\mathrm{P}$ deficiency. Upon termination of the experiment, $\mathrm{P}$ deficiency symptoms of chlorosis, necrosis, and leaf abscission occurred on plants grown without $\mathrm{P}$ or with a continuous concentration of $2.5 \mathrm{mg} \cdot \mathrm{L}^{-1} \mathrm{P}$ (J.B. Henry, visual observations). Plants grown without $\mathrm{P}$ also did not set fruit and had similar height as when they were initially transplanted. Additionally, all plants switched to a $0 \mathrm{mg} \cdot \mathrm{L}^{-1} \mathrm{P}$ fertilization regiment developed at least some level of $\mathrm{P}$ deficiency symptoms after 3 weeks without $P$. The fact that symptoms developed on plants grown with the highest initial P concentration illustrates how P may be restricted to control growth; however, $\mathrm{P}$ was still required to maintain healthy growth.

Analysis of the most recently matured foliage demonstrates how tissue $\mathrm{P}$ concentrations change with fertilizer $P$ concentrations over time (Table 3 ). Tissue P concentrations were highest for plants grown with $20 \mathrm{mg} \cdot \mathrm{L}^{-1}$ $\mathrm{P}$ at weeks 6 and 9 (Table 3). At week 11, however, $\mathrm{P}$ tissue values decreased significantly compared with what they were 2 weeks earlier. In fact, tissue $P$ concentrations for plants grown with $20 \mathrm{mg} \cdot \mathrm{L}^{-1} \mathrm{P}$ for 11 weeks were nearly half what they had been at week 9. Tissue $\mathrm{P}$ concentrations also decreased in plants grown with $10 \mathrm{mg} \cdot \mathrm{L}^{-1} \mathrm{P}$, from their highest point at week 6 . Some of this decrease in tissue $\mathrm{P}$ concentrations may 
be attributed to the fact that pepper plants were developing fruit by week 8 , and the fruit were acting as a sink for $\mathrm{P}$ in the vegetative tissues (Marschner, 1995). There were no other significant decreases in plant tissue $\mathrm{P}$ concentrations over time for peppers grown with continuous $\mathrm{P}$ concentrations less than $10 \mathrm{mg} \cdot \mathrm{L}^{-1} \mathrm{P}$ or for any restricted $\mathrm{P}$ treatment.

These trends all illustrate how pepper plants limited by $\mathrm{P}$ have low levels of $\mathrm{P}$ in the substrate, as they absorbed most of what was available. This rapid response makes it feasible to implement a low P $\left(2.5-5 \mathrm{mg} \cdot \mathrm{L}^{-1}\right)$ fertilization shift during production once the
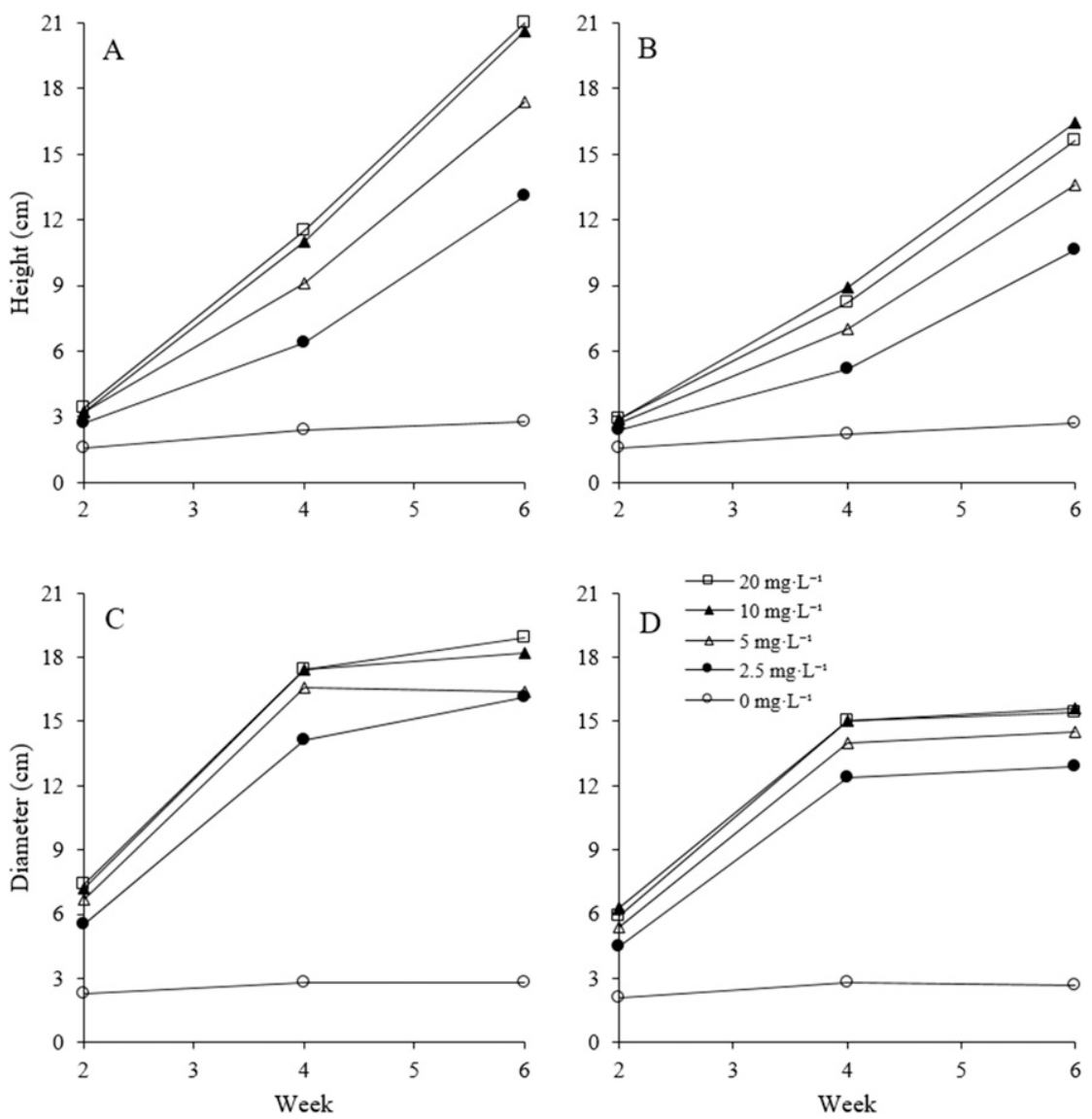

Fig. 4. Effect of five different fertilizer P concentrations on growth means of vinca (Catharanthus roseus) 'Cora Burgundy' and 'Pacifica XP Blush' over a 6-week period. Growth in terms of (A) height and (C) diameter of 'Cora Burgundy', compared with (B) height and (D) diameter of 'Pacifica XP Blush'.
$\mathrm{P}$ concentrations in terms of GI for each cultivar grown in this study. Overall, $\mathrm{P}$ concentrations ranging from 6.4 to 13.1 $\mathrm{mg} \cdot \mathrm{L}^{-1} \mathrm{P}$ resulted in maximum growth. Using $\mathrm{P}$ concentrations lower than the maximum concentration in Table 1 can be used to control growth in the corresponding species; however, the range for growth control was small and may be difficult to successfully manipulate in a commercial setting. Concentrations of $2.5 \mathrm{mg} \cdot \mathrm{L}^{-1} \mathrm{P}$ typically led to the development of $\mathrm{P}$ deficiency symptoms, depending on the species.

These results deviate from the findings of Hansen and Nielsen (2000, 2001), where significant growth control was not achieved in Argyranthemum, Aster, Pentas, and Rosa when lowering $\mathrm{P}$ concentrations from 31 to $4.7 \mathrm{mg} \cdot \mathrm{L}^{-1}$. Hansen and Nielsen $(2000,2001)$ reported that $\mathrm{P}$ concentrations of $1.5 \mathrm{mg} \cdot \mathrm{L}^{-1}$ provided significant height control when compared with their highest concentration of $31 \mathrm{mg} \cdot \mathrm{L}^{-1} \mathrm{P}$. Although their findings agree with this study, $\mathrm{P}$ concentrations of $2.5 \mathrm{mg} \cdot \mathrm{L}^{-1}$ typically led to plants that were extremely small and developed mild symptoms of $\mathrm{P}$ deficiency. Results from Hansen and Nielsen $(2000,2001)$ indicated that growing plants with just $1.5 \mathrm{mg} \cdot \mathrm{L}^{-1}$ provided significant growth control with no detrimental effects on appearance or flowering.

The discrepancy between the findings of this study and the findings of Hansen and Nielsen $(2000,2001)$ may be explained by the differences in substrate and fertility. Hansen and Nielsen $(2000,2001)$ used kiln dried clay as the substrate, which was treated with a $\mathrm{P}$ buffer. This buffer supplied $\mathrm{P}$ at a constant concentration that releases steadily on each irrigation, rather than being supplied through a liquid fertilizer. This is because certain clays such as Allophane have a very high ability to adsorb and deliver P over time (Oh et al., 2016). This $\mathrm{P}$ buffer provided a more constant low P supply (Borch et al., 1998; Oh et al., 2016), thus preventing deficiency symptoms from developing even when $\mathrm{P}$ concentrations are very low. In fact, other studies have found that plants grown in P-buffered substrates can achieve maximum growth with just $0.093 \mathrm{mg} \cdot \mathrm{L}^{-1} \mathrm{P}$ (Borch et al., 1998). This low concentration would result in

Table 2. Least squared means and differences for growth parameters of ornamental pepper (Capsicum annuum 'Tango Red') at experiment termination.

\begin{tabular}{|c|c|c|c|c|c|c|c|}
\hline \multirow[b]{2}{*}{ Fertilization regimen ${ }^{z}$} & \multirow[b]{2}{*}{ Phosphorus concn $\left(\mathrm{mg} \cdot \mathrm{L}^{-1}\right)$} & \multicolumn{6}{|c|}{ Growth parameter } \\
\hline & & $\mathrm{Ht}(\mathrm{cm})$ & Diam $(\mathrm{cm})$ & Dry mass $(\mathrm{g})$ & Growth index & $\mathrm{pH}$ & $\mathrm{EC}^{\mathrm{y}}$ \\
\hline \multirow{2}{*}{ Continuous } & 2.5 & $13.7 \mathrm{~cd}$ & $16.6 \mathrm{de}$ & $0.7 \mathrm{ef}$ & $10.3 \mathrm{e}$ & $6.9 \mathrm{bc}$ & $1.4 \mathrm{c}$ \\
\hline & 20 & $22.2 \mathrm{ab}$ & $41.1 \mathrm{a}$ & $9.3 \mathrm{a}$ & $24.2 \mathrm{a}$ & $7.4 \mathrm{a}$ & $2.7 \mathrm{~b}$ \\
\hline \multirow[t]{2}{*}{ Restricted } & 2.5 & $12.9 \mathrm{~d}$ & $13.6 \mathrm{e}$ & $0.4 \mathrm{fg}$ & $9.0 \mathrm{e}$ & $7.0 \mathrm{bc}$ & $1.2 \mathrm{c}$ \\
\hline & 5 & $16.1 \mathrm{c}$ & $18.7 \mathrm{~d}$ & $1.3 \mathrm{e}^{\circ}$ & $12.0 \mathrm{~d}$ & $6.9 \mathrm{c}$ & $1.3 \mathrm{c}$ \\
\hline
\end{tabular}

${ }^{\mathrm{z}}$ Continuous phosphorus (P) plants were grown with $0,2.5,5,10$, or $20 \mathrm{mg} \cdot \mathrm{L}^{-1} \mathrm{P}$. Restricted P plants were grown with initial concentrations of $2.5,5$, 10 , or $20 \mathrm{mg} \cdot \mathrm{L}^{-1} \mathrm{P}$ for 6 weeks, that was then restricted to $0 \mathrm{mg} \cdot \mathrm{L}^{-1} \mathrm{P}$ for 5 weeks.

${ }^{\mathrm{y}} \mathrm{EC}=$ electrical conductivity.

${ }^{\mathrm{x}}$ Lower case letters signify minimum significant differences among all $\mathrm{P}$ concentrations for each growth parameter. Means with different letters are significantly different at $P \leq 0.05$. 
Table 3. Least squared means and minimum significant differences for most recently matured leaf tissue phosphorus (P) concentrations in ornamental pepper (Capsicum annuum 'Tango Red'), at 6, 9, and 11 weeks after transplant.

\begin{tabular}{|c|c|c|c|c|c|c|c|c|c|}
\hline \multirow[b]{3}{*}{ Wk } & \multirow[b]{3}{*}{0} & \multicolumn{8}{|c|}{ Fertilizer phosphorus concn $\left(\mathrm{mg} \cdot \mathrm{L}^{-1}\right)^{\mathrm{z}}$} \\
\hline & & \multicolumn{4}{|c|}{ Continuous } & \multicolumn{4}{|c|}{ Restricted } \\
\hline & & 2.5 & 5 & 10 & 20 & 2.5 & 5 & 10 & 20 \\
\hline 6 & $0.11^{\mathrm{y}}$ & $0.16 \mathrm{C} \mathrm{de}^{\mathrm{x}}$ & $0.19 \mathrm{C}$ cde & $0.39 \mathrm{~B} \mathrm{~b}$ & $0.55 \mathrm{~A} \mathrm{a}$ & ${ }^{\mathrm{w}}$ & - & - & - \\
\hline 9 & 0.10 & $0.14 \mathrm{~B}$ de & $0.13 \mathrm{~B}$ de & $0.21 \mathrm{~B} \mathrm{~cd}$ & $0.51 \mathrm{~A} \mathrm{a}$ & $0.11 \mathrm{~B} \mathrm{de}$ & $0.11 \mathrm{~B}$ de & $0.11 \mathrm{~B}$ de & $0.14 \mathrm{~B}$ de \\
\hline 11 & 0.12 & $0.13 \mathrm{CD}$ de & $0.16 \mathrm{BC}$ de & $0.19 \mathrm{~B}$ cde & $0.27 \mathrm{~A} \mathrm{c}$ & $0.10 \mathrm{D} \mathrm{e}$ & $0.14 \mathrm{C} \mathrm{de}$ & $0.15 \mathrm{C}$ de & $0.10 \mathrm{D} \mathrm{e}$ \\
\hline
\end{tabular}

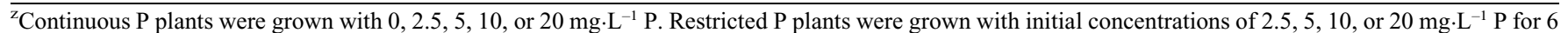
weeks, that was then restricted to $0 \mathrm{mg} \cdot \mathrm{L}^{-1} \mathrm{P}$ for 5 weeks.

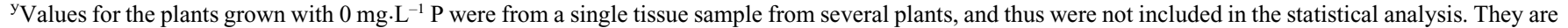
reported only for reference.

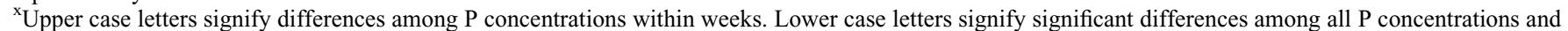
weeks. Means with different letters are significantly different at $P \leq 0.05$.

${ }^{\text {w}}$ No measurable data.

detrimental P-deficiency symptoms in the peat based substrates typically used in bedding plant production. Peat-based substrates have a very low ability to adsorb $\mathrm{P}$, and thus, $\mathrm{P}$ leaches out of the substrate quite readily (Marconi and Nelson, 1984). In this study, a peat- and perlite-based substrate was used in conjunction with a constant liquid feed fertilization program, which is more typical of practices used in greenhouse production of ornamental bedding plants. As the methods in this study replicate typical production practices, results may be used directly to provide fertilizer recommendations to growers.

Much of the low P work that has been done with bedding plants has used a P buffer and have suggested using $\mathrm{P}$ concentrations ranging from 0.093 to $1.5 \mathrm{mg} \cdot \mathrm{L}^{-1}$ for compact and healthy growth (Borch et al., 1998; Hansen and Nielsen, 2000, 2001). Borch et al. (1998) used low P to investigate the effects of growth control on bedding impatiens (Impatiens walleriana Hook. f.) and French marigold (Tagetes patula L.); however, P buffered substrate was compared with liquid feed fertilization. Plants were grown using P-buffer concentrations of 0.093 and $0.28 \mathrm{mg} \cdot \mathrm{L}^{-1}$ and compared with plants grown using liquid feed fertilization with a $\mathrm{P}$ concentration of $46.5 \mathrm{mg} \cdot \mathrm{L}^{-1}$. Even with these differences in $\mathrm{P}$ concentration, no significant height control was observed in either species (Borch et al., 1998). Conversely, significant growth control was achieved for each species grown in this study by using $\mathrm{P}$ concentrations below 5-10 $\mathrm{mg} \cdot \mathrm{L}^{-1}$.

\section{Conclusions}

In most cases, plants required very low $\mathrm{P}$ concentrations compared with other essential macronutrients to achieve maximum growth. Species grown in this study required about 5 $15 \mathrm{mg} \cdot \mathrm{L}^{-1} \mathrm{P}$ to achieve maximum growth, indicating that many common commercial fertilizers supply far more $P$ than greenhouse bedding plants require. For instance, $20 \mathrm{~N}-$ $8.7 \mathrm{P}-16.6 \mathrm{~K}$ mixed at a low rate of $100 \mathrm{mg} \cdot \mathrm{L}^{-1}$ $\mathrm{N}$ would supply crops with $\approx 43 \mathrm{mg} \cdot \mathrm{L}^{-1} \mathrm{P}$. This amount of $P$ can be roughly seven times greater than necessary for species such as vinca, which reached maximum growth with $\approx 6 \mathrm{mg} \cdot \mathrm{L}^{-1} \mathrm{P}$. Results from this experiment illustrate how little $\mathrm{P}$ is required for most greenhouse species and may be directly applied to growing techniques to improve fertilization strategies.

Although P concentrations may be significantly lowered relative to current practices and recommendations, it is still important to note that different species have different $\mathrm{P}$ requirements for optimal growth (Table 1). For instance, vinca required about $6 \mathrm{mg} \cdot \mathrm{L}^{-1} \mathrm{P}$ to achieve maximum growth, while ornamental peppers required roughly $15 \mathrm{mg} \cdot \mathrm{L}^{-1} \mathrm{P}$. Higher $\mathrm{P}$ concentrations may be required by ornamental peppers to support fruit development. This is further evidenced by the fact that leaf tissue $\mathrm{P}$ concentrations decreased in $P$ sufficient plants as peppers were developing and maturing. It has been found that remobilized $\mathrm{N}$ and $\mathrm{P}$ can account for $90 \%$ of these elements in developing flowers and fruit, indicating high $P$ requirements to support these reproductive structures (Epstein and Bloom, 2005; Marschner, 1995).

Several commercial fertilizers can be used by growers to supply optimal $\mathrm{P}$ concentrations in the range of $5-15 \mathrm{mg} \cdot \mathrm{L}^{-1}$. For instance, $13 \mathrm{~N}-0.9 \mathrm{P}-10.8 \mathrm{~K} \mathrm{Cal} \mathrm{Mag} \mathrm{mixed} \mathrm{at}$ $75-225 \mathrm{mg} \cdot \mathrm{L}^{-1} \mathrm{~N}$, or $15 \mathrm{~N}-2.2 \mathrm{P}-12.5 \mathrm{~K} \mathrm{Cal}$ Mag mixed at $50-100 \mathrm{mg} \cdot \mathrm{L}^{-1} \mathrm{~N}$ could be used to supply 5-15 $\mathrm{mg} \cdot \mathrm{L}^{-1} \mathrm{P}$. In addition, growers may alternate between two commercial fertilizers to apply an average within this optimal range of $\mathrm{P}$. For instance, a high $\mathrm{P}$ fertilizer formulation such as $20 \mathrm{~N}-4.4 \mathrm{P}-$ $16.6 \mathrm{~K}$ mixed at $100 \mathrm{mg} \cdot \mathrm{L}^{-1} \mathrm{~N}$ could be used in conjunction with a low $\mathrm{P}$ fertilizer such as $13 \mathrm{~N}-0.9 \mathrm{P}-10.8 \mathrm{~K}$ Cal Mag.

\section{Literature Cited}

Borch, K., K.M. Brown, and J.P. Lynch. 1998. Improving bedding plant quality and stress resistance with low phosphorus. HortTechnology 8:575-579.

Cavins, T.J., B.E. Whipker, and W. Fonteno. 2005. Timing of PourThru affects $\mathrm{pH}$, electrical conductivity, and leachate volume. Commun. Soil Sci. Plant Anal. 36:1573-1581.

Epstein, E. and A. Bloom. 2005. Mineral nutrition of plants: Principles and perspectives. 2nd ed. Sinauer Associates, Sunderland, MA.
Hansen, C.W. and K.L. Nielsen. 2000. Nonchemical growth regulation of ornamental plants. Grøn Viden 121:1-4.

Hansen, C.W. and K.L. Nielsen. 2001. Reduced phosphorus availability as a method to reduce chemical growth regulation and to improve plant quality, p. 314-315. In: W.J. Horst, M.K. Schenk, A. Bürkert, N. Claassen, H. Flessa, W.B. Frommer, H. Goldbach, H. Olfs, V. Römheld, B. Sattelmacher, U. Schmidhalter, S. Schubert, N. von Wirén, and L. Wittenmayer (eds.). Plant nutrition - Food security and sustainability of agro-ecosystems. Springer, Dordrecht, The Netherlands.

Henry, J.B. 2017. Beneficial and adverse effects of low phosphorus fertilization of floriculture species. MS Thesis, N.C. State Univ., Raleigh

Krug, B.A., B.E. Whipker, I. McCall, and B. Cleveland. 2010. Geranium leaf tissue nutrient sufficiency ranges by chronological age. J. Plant Nutr. 33(3):339-350.

Marconi, D. and P. Nelson. 1984. Leaching of applied phosphorus in container media. Sci. Hort. 22(3):275-285.

Marschner, H. 1995. Mineral nutrition of higher plants. 2nd ed. Academic Press, San Diego, CA.

McMahon, R.W. 2011. An introduction to greenhouse production. 3 rd ed. Curriculum Materials Service, Columbus, OH.

Mengel, K., E.A. Kirkby, H. Kosegarten, and T. Appel. 2001. Principles of plant nutrition. 5th ed. Kluwer Academic Publishers, Dordrecht, The Netherlands.

Mills, H.A. and J.B. Jones, Jr. 1996. Plant analysis handbook II. A practical sampling, preparation, analysis, and interpretation guide. MicroMacro Publishing, Inc., Athens, GA

Nelson, P.V., C.Y. Song, and J.S. Huang. 2002. What really causes stretch? GPN Magazine, Jan. 2002. <http://www.gpnmag.com/whatreally-causes-stretch>.

Nelson, P.V., C.-Y. Song, J.S. Huang, C.E. Niedziela Jr., and W.H. Swallow. 2012. Relative effects of fertilizer nitrogen form and phosphate level on control of bedding plant seedling growth. HortScience 47:249-253.

Oh, Y., P.V. Nelson, D.L. Hesterberg, and C.E. Niedziela. 2016. Efficacy of a phosphatecharged soil material in supplying phosphate for plant growth in soilless root media. Intl. J. Agron. 2016:1-10.

Spiess, A. and N. Neumeyer. 2010. An evaluation of $R^{2}$ as an inadequate measure for nonlinear models in pharmacological and biochemical research: A Monte Carlo approach. BMC Pharmacol. 10(1):6. 